\title{
THE EFFECT OF VOCABULARY MASTERY TOWARD THE READING COMPREHENSION SKILL FOR THE STUDENTS GRADE VIII IN THE STATE OF JUNIOR HIGH SCHOOL IN BEKASI DISTRICT
}

\author{
Mukhlasul Fasikh \\ STIBA IEC Jakarta \\ mukhlasul@stibaiecjakarta.ac.id
}

\begin{abstract}
This study aims to check out the effect of vocabulary mastery toward the reading comprehension skill in the State of Junior High School in Bekasi District. The method used in this research is expose facto with the correlation and regression analysis that is connecting between data showing the level vocabulary mastery toward the reading comprehension skill of students in the State of Junior High School in Bekasi District. Sampling was done by random sampling technique. The respondents are 80 students in this research. The research instruments were the test questions with multiple choice forms. The result showed that there is a significant influence of vocabulary mastery toward the reading comprehension skill of English Language on students Grade VIII in the State of Junior High School in Bekasi District. This is evidenced by the acquisition of Sig value. $0.003<0.05$ and th $=3.019$. Variable vocabulary mastery contributed $13.86 \%$ in improving the reading comprehension skill.
\end{abstract}

Keywords: Learning Styles, Vocabulary Mastery, Reading Comprehension Skill.

\section{A. INTRODUCTION}

\section{Background}

English is a very important language in our lives these days. English is used extensively in science, knowledge and technology as well as education, business, transcation, and other activities in the world. Every country in the world has one language that is used as a communication tool and as a national language. Therefore, the mastery of English is an absolute requirement to establish relationships between these countries. Larry E. Smith (1983: 9) states, "English is a means to communicate to the rest of the world, their identity, culture, politics, 
religion, and 'way of life'." In learning English, the learner must master the four basic language skills. The reading skill is one of the most important skills to learn because it is one of the most important ways to improve the general proficiency of language in English such as; enriching vocabulary, improving students' understanding of reading skill.

In the current era, reading is done every day, morning, afternoon, and evening, even before a bedtime. So reading skill is very important for people who mostly learn English and how they master vocabulary in reading. In order to communicate properly, one must master the vocabulary. The more people master vocabulary the easier for them to convey their ideas. Gorys Keraf (1986: 88) argues that in words one can think, express feelings and ideas. To be able to express ideas and suggestions, both orally and in writing, it is necessary to choose the proper meaning of the word. That is because one word in English can have more than one meaning (multiple meanings) in Indonesian and vice versa, there is more than one word in English that has the same meaning or similar to another word (synonym) in the Indonesian language.

Writers, readers, and speakers should look at situations related to one event to select the right vocabulary to express it. Kamil and Hiebert (2005: 3) state "Failure to distinguish between the different kinds of vocabulary can lead to confusion and disagreement ... vocabulary is the knowledge of meanings of words". Problems will also exist or occur when students do not master vocabulary. The most important thing about learning vocabulary is also emphasized by Horwits and Taylor (in Schmitt and McCorthy, 1997: 201) who say that, "a large number of ESL students solve the question of whether or not they agree very strongly which is the most important part of language learning foreign is the vocabulary ".

Based on the explanation above, the author will conduct field research. The study wanted to use both as two complementary variables to know the effect of vocabulary mastery toward the reading comprehension skill in the State of Junior High School in Bekasi District.

\section{Objective}


The purpose of this research is to know the effect of vocabulary mastery toward the reading comprehension skill in the State of Junior High School in Bekasi District.

\section{Theoretical Framework}

\subsection{Reading}

There are several definitions about reading from various ones. Hodgson in the book Reading the work of Tarigan (2008: 7) states that reading is a process done and used by readers to obtain messages, which would be conveyed by the author through the words media or written language. Understanding the reading is a reading strategy that aims to provide an assessment of the reading that involves the readings and make the appropriate analysis (Achmad HP, 2010: 81). In the process of reading, there are two factors involved in it. Both factors include reading factor and reader factor. As Cole reveals reading is the psychological process of determining the meaning of a written word. Reading involves sight, eye movement, inner speech, memory, knowledge of a word that can be understood, and reading experiences (Wiryodijoyo, 1989: 42).

The reading skill is related to the ability to understand the content of the reading. According to Zints (1980:37), there are four stages in the process of reading: "Perception, understanding, reaction, and the ability to read words as meaningful union. Comperehension is the ability to get writers to generate useful thoughts as read in the context." According to Amran Halim, he states that the speed of reading in question is the speed that does not ignore his comprehension. Reading speed is about 1 minute to read about 250 words. The 1 minute time includes the time it takes to read the quote on which the question is based. (1982:186)

In relation to the reading comprehension skill, reading can be said to get something to be known, to learn to do, to get pleasure and knowledge and writing something (Semi, 1990: 100). And some restrictions on reading above, it can be concluded that reading is a process to understand the content submitted by the author through his writing. 


\subsection{Reading Comprehension Skill}

In connection with the reading comprehension skill, there are several aspects to note (Semi, 1990: 41-42):

1) The written language and symbols aspects.

a) The ability to understand words and terms,

b) The ability to understand the patterns of sentences and formations that are increasingly long and difficult,

c) The ability to correctly interpret the symbols or signs used in the written language.

\section{2) The author's ideas Aspects.}

a) The ability to recognize the main intent and idea expressed in the essay.

b) The ability to understand ideas that support the main idea.

c) The ability to draw the right conclusions

\section{3) The tone and style aspects.}

a) The ability to recognize the author's attitudes toward the issues he poses and the author's attitude to the reader.

b) The technical abilities and writing styles used by the author.

In reading, each reader has the ability to absorb what the author submitted. The reading comprehension skill signifies the effectiveness of reading. "Someone is said comprehence the content of the reading if one is able to answer $40-60 \%$ (minimum $50 \%$ ) or if the reader can answer correctly half and the number of questions" (Nurhadi, I 987: 40). Although someone is said to comprehence a 50\% reading and the number of questions, the reading skills of students needs to be improved so that students have adequate reading skills.

\subsection{Mastery}


The definition of Mastery by W.J.S. Poerwadarminta in Indonesian Big Dictionary is a word derived from the basic word 'power' which means understanding or the skill to use the wording or skill (2002: 604). Nurgiyantoro (2001: 162) states that mastery is the ability of a person who can be realized both from theory and practice. A person can be said to master something if the person understands and comprehence the material or concept so that it can apply it to a new situation or concept. From these two concepts, it can be concluded that the mastery is the ability of a person in comprehence the material or concepts that can be realized both theory and practice.

\subsection{Vocabulary}

The person who is good at choosing the vocabulary correctly will generate interest in the listener. He will speak fluently, communicatively, and variatively, so it is not boring. By words, one can think, express feeling and ideas. (Gorys Keraf, 1986:88). In line with Keraf, Nurgiyantoro (2001:213) argues that vocabulary, lexicon, is a word possessed by a language.

Harimurti Kridalaksana in DjagoTarigan (1991: 441) states that the vocabulary is the same as the lexicon. The lexicon is (1) a language component that contains information about the meaning and usage of the word in the language; (2) a richness of word is possessed by a speaker, author or a language; and (3) a list of words is compiled like a dictionary, but with a brief and practical explanation. According to Nasution's vocabulary in detail can be explained as follows: (a) All words contained in a language; (b) words controlled by a person or words used by a group of people from the same environment; (c) the words used in a field of science; (d) a linguistic list of all morpheme presented in a language; and (e) a list of words and phrases from an alphabetically arranged language is with its limits and descriptions (Nasution 1985: 26)

In line with Nasution, Adiwinta in Acts (1991: 41) states that vocabulary is defined as follows:

1) All words contained in the language; 
2) Words controlled by a person or words used by a group of people from the same environment;

3) Words used in science;

4) In linguistics, although all morphemes in one particular language are not vocabulary, but most of the morphemes are known as a vocabulary; and

5) There are a number of words, phrases, and terms of an alphabetically arranged language with limits and captions.

Those opinions have in common that the vocabulary is a collection of words possessed by a person of a language. And the vocabulary that someone controls in an environment will be different from the vocabulary in the other environment.

From some opinions above, it can be concluded that the vocabulary is a wealth of words that are owned and used by someone in the activities of language to express the thoughts and feelings in various spheres of life.

\subsection{Vocabulary Mastery}

In order to communicate properly one must master the vocabulary. The more a person's vocabulary becomes easier to convey his ideas. A person who has extensive knowledge in the use of vocabulary will find it easier to understand a passage. Harmer (1991:153) states, "If the language structures make up the skeleton of the language, then it is the vocabulary that provides the vital organs and the flesh". Akhadiah argues that "The use of vocabulary quantitatively means the scope of a vocabulary controlled by a person of a language, while the use of a vocabulary qualitatively means understanding the meaning of a vocabulary controlled by a person of a language." (1996: 95)

H.G. Tarigan said that the quality of a person's language skills clearly depends on the quantity and quality of his vocabulary. The more vocabulary a person possesses, the greater the likelihood he is skilled at speaking (1986: 2). Nurgiyantoro (2001: 213) adds that there are various aspects to be considered in the selection of vocabularies to be tested. These aspects are: 1) Vocabulary test material 2) Level of vocabulary test used by Bloom taxonomy

Testing vocabulary mastery according to John Read (2000: 16) is that Vocabulary is knowledge involves knowing the meanings of words and the purpose 
of the vocabulary is synonym, a dictionary - definition tape, or an equivalent word in their own language. Scott Thornburry (2002) argues that this type of vocabulary consists of Word classes, Word families, Word Formation, Word Unit Compounds, Kolokasi, Homonim, Synonyms and Antonim. While Harmer (1991:158) concluded that understanding vocabulary means knowing about the meaning, the use of words, the formation of words, and the word grammar. He also adds (2001:16) that there are several aspects to be discussed in the vocabulary, namely: the variety of meanings of words (synonyms, antonyms, connotations, and denotations), contextual meanings such as idioms, word combinations (collocations), and words in grammar (nouns, verbs, adjectives, and adverbs).

From the experts' explanation above, it can be concluded that the vocabulary mastery is the ability or skill of students in understanding the meaning of a word in the language based on aspects that are tailored to their grade level or ability.

\subsection{Methodology}

Based on the focus of the problems and objectives to be achieved, this research belongs to the expose facto method because it looks for causal relationships or factors that influence by collecting data from vocabulary mastery in improving the reading comprehension skill. This study uses correlational analysis technique that is a technique designed to determine how much influence between independent variables with dependent variables. The research was conducted at State Junior High School located in Bekasi District, namely SMP Negeri 5 Setu and SMP Negeri 1 Setu in Bekasi Regency. The study time is scheduled to begin in August to December 2016. It's begun with observation or pre-field.

Research stages include Pre-survey, Test Instrument, Data Collection, Data Analysis and Data Writing. Data and information in the field were collected with the help of objective tests. To shorten the time, as well as the use of technology, the calculation of descriptive statistics in this study will be completed by using the help of computer program SPSS 20.0. According to Professor and director of research and development Jack R. Fraenkel and Norman E. Wallen: "In a simple form, correlational research investigates the possibility of relationships between only two 
variables, although investigations of more than two variables are common." (Fraenkel, 2007 : 335).

\section{B. RESULT AND DISCUSSION}

\section{Deskripsi Data}

\subsection{Data Kemampuan Memahami Bacaan Bahasa Inggris(Y)}

The data of English reading comprehension skill is obtained from 80 students who become the research sample. The value obtained is the lowest 60 , the highest 95 , the average of 80.69 , the median of 80.00 , the mode of 80 and the standard deviation of 9.062 .

Table 4.1. Description of Research Data in Reading Comprehension Skill

\begin{tabular}{|c|c|c|}
\hline \multicolumn{3}{|c|}{ Statistics } \\
\hline \multicolumn{3}{|c|}{ reading comprehension skill } \\
\hline \multirow{2}{*}{$N$} & Valid & 80 \\
\hline & Missing & 0 \\
\hline \multicolumn{2}{|c|}{ Mean } & 80.69 \\
\hline \multicolumn{2}{|c|}{ Median } & 80.00 \\
\hline \multicolumn{2}{|c|}{ Mode } & 80 \\
\hline \multicolumn{2}{|c|}{ Std. Deviation } & 9.062 \\
\hline \multicolumn{2}{|c|}{ Minimum } & 60 \\
\hline \multicolumn{2}{|c|}{ Maximum } & 95 \\
\hline
\end{tabular}

If it is viewed from the results of the above calculation, it can be said that the reading comprehension skill of class VIII in the State of Junior High School in Bekasi District is quite good. This is indicated by an average score of 80.69 .

To clarify the above data, illustrated in the histogram as follows: 


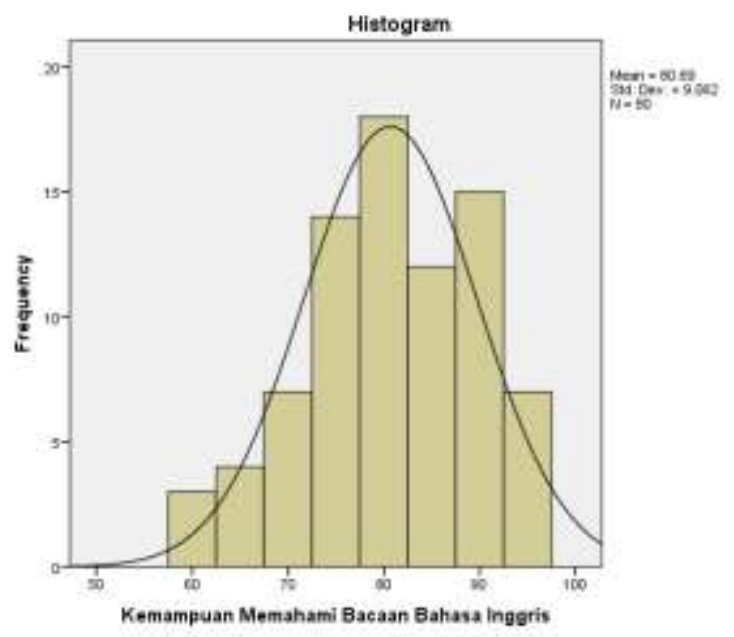

Figure 4.1. Histogram of Variable Polygon of English Reading Comprehesion Skill

From the histogram and polygon frequency above can be concluded that the the reading comprehension skill of class VIII in the State of Junior High School in Bekasi District has a normal distribution.

\subsection{Vocabulary Master Data (X)}

The Data of vocabulary mastery obtained from the questionnaire score answered 80 students as respondents is produced the lowest value 60 , the highest value 95 , the average value of 79.81 , median of 80.00 , the mode of 70 and standard deviation of 10.597 .

Table 4.2. Description of Research Data on Vocabulary Mastery

\begin{tabular}{|c|c|c|}
\hline \multicolumn{3}{|c|}{ Statistics } \\
\hline \multicolumn{3}{|c|}{ Vocabulary mastery } \\
\hline \multirow{2}{*}{$N$} & Valid & 80 \\
\hline & Missing & 0 \\
\hline \multicolumn{2}{|c|}{ Mean } & 79.81 \\
\hline \multicolumn{2}{|c|}{ Median } & 80.00 \\
\hline
\end{tabular}




\begin{tabular}{|l|r|}
\hline Mode & 70 \\
\hline Std. Deviation & 10.597 \\
\hline Minimum & 60 \\
\hline Maximum & 95 \\
\hline
\end{tabular}

From the calculation above, it can be said that the vocabulary mastery of of class VIII in the State of Junior High School in Bekasi District is quite good. This is indicated by the acquisition of the average score of student vocabulary score 79.81 .

To clarify the above data, it is illustrated in the histogram as follows:

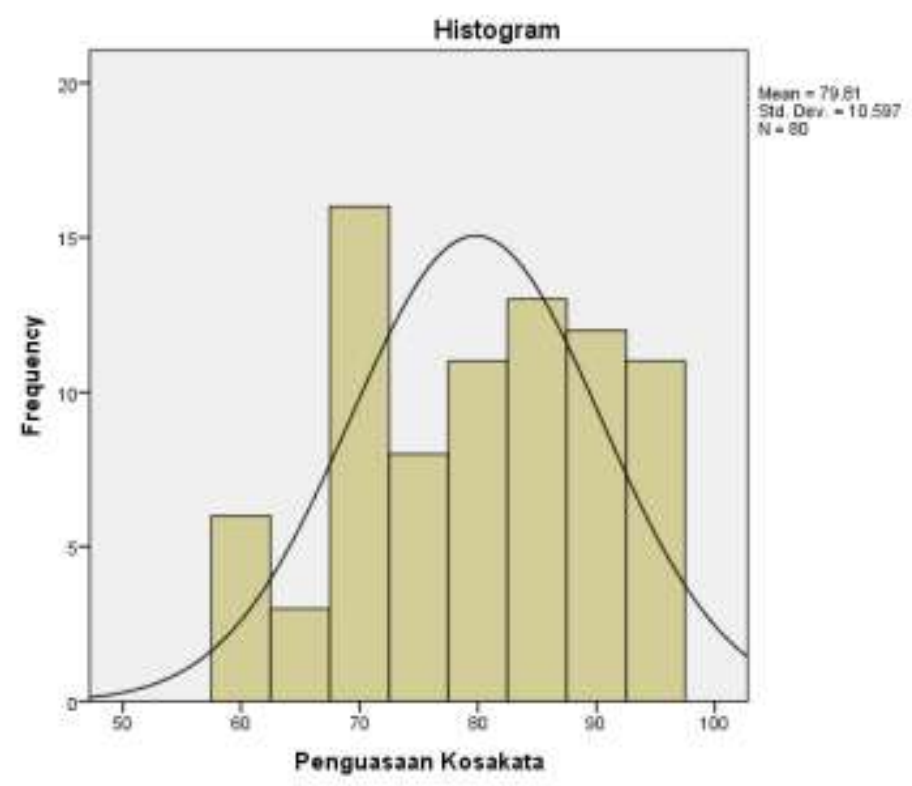

Figure 4.2. Polygon Histogram Variable Vocabulary Mastery

From the histogram and polygon frequency above can be concluded that the vocabulary mastery of of class VIII in the State of Junior High School in Bekasi District has a normal distribution.

\section{The Test Requirements of Regression Analysis}

\subsection{Classic Assumption Test}

a. Data Normality Test 
The good regression requirement is if the research data follows a normal distribution.

Table 4.3. Data Normality Test

\begin{tabular}{|c|c|c|c|}
\hline \multicolumn{4}{|c|}{ One-Sample Kolmogorov-Smirnov Test } \\
\hline & & $\begin{array}{c}\text { Kemampuan } \\
\text { Memahami } \\
\text { Bacaan } \\
\text { Bahasa } \\
\text { Inggris }\end{array}$ & $\begin{array}{c}\text { Penguasaan } \\
\text { Kosakata }\end{array}$ \\
\hline \multicolumn{2}{|l|}{$\mathrm{N}$} & 80 & 80 \\
\hline \multirow[b]{2}{*}{$\begin{array}{l}\text { Normal } \\
\text { Parameters }{ }^{a} \\
\text {,b }\end{array}$} & Mean & 80.69 & 79.81 \\
\hline & \begin{tabular}{|l} 
Std. \\
Deviatio \\
n
\end{tabular} & 9.062 & 10.597 \\
\hline \multirow{3}{*}{$\begin{array}{l}\text { Most } \\
\text { Extreme } \\
\text { Differences }\end{array}$} & $\begin{array}{l}\text { Absolut } \\
\text { e }\end{array}$ & .123 & .138 \\
\hline & Positive & .105 & .135 \\
\hline & $\begin{array}{l}\text { Negativ } \\
\text { e }\end{array}$ & -.123 & -.138 \\
\hline \multicolumn{2}{|c|}{$\begin{array}{l}\text { Kolmogorov-Smirnov } \\
\text { Z }\end{array}$} & 1.100 & 1.232 \\
\hline \multicolumn{2}{|c|}{ Asymp. Sig. (2-tailed) } & .178 & .096 \\
\hline \multicolumn{4}{|c|}{ a. Test distribution is Normal. } \\
\hline \multicolumn{4}{|c|}{ b. Calculated from data. } \\
\hline
\end{tabular}

From the table above, it shows that hypothesis test that states the distribution of data in this regression analysis follows the normal distribution. This is indicated by all Asymp values. Sig $>0.05$. This means that all data is normally distributed. 


\section{b. Heteroscedasticity Test}

The notion of heteroscedasticity is when the observed error or residual has no constant variant. The condition of heteroscedasticity often occurs in cross section data, or data taken from some respondents at a given time.

One method of detecting heteroscedasticity is to create standardized Residual (ZRESID) and Standardized Predicted Value (Y cap) scatter plots. In the picture below shows no change $e$ as long as $Y$ cap, then stated no heteroskedastisitas on error (error / residual) it.

Scatterplot

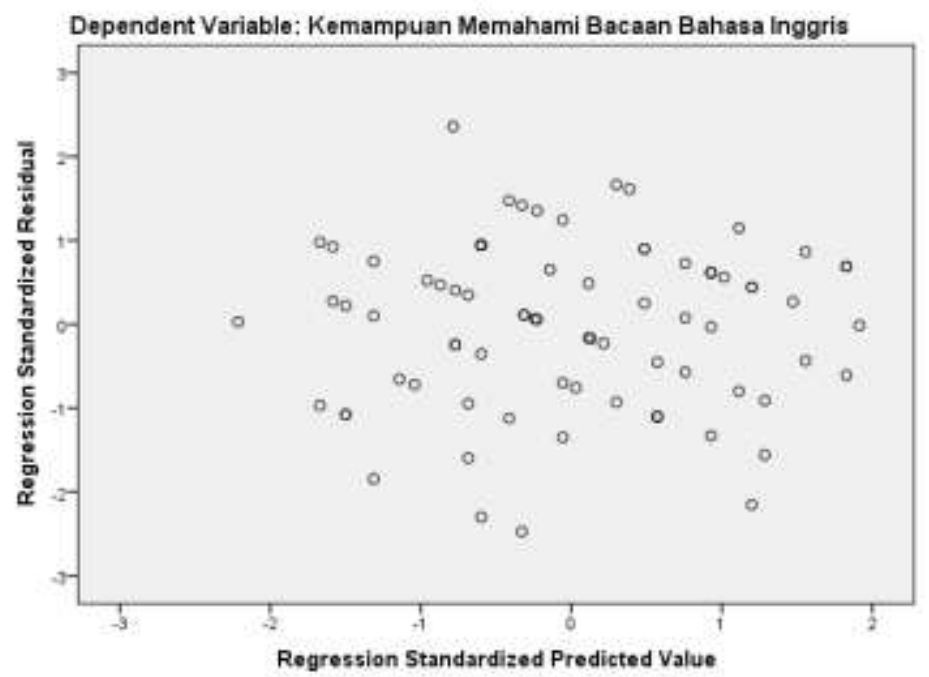

Gambar 4.3. Scatterplot of Heteroscedasticity test

From the picture above shows that the points spread randomly and did not form a certain clear pattern, as well as scattered above or below the number 0 on the $\mathrm{Y}$ axis. This shows that there is no heteroscedasticity in the regression model, so it can be used to predict variable of reading comprehension skill based on vocabulary mastery

\section{c. Galat Normality Test}


The good regression requirement is if the research data follows a normal distribution.

Table 4.4. Error Normality Test

\begin{tabular}{|c|c|c|}
\hline \multicolumn{3}{|c|}{ One-Sample Kolmogorov-Smirnov Test } \\
\hline & & $\begin{array}{c}\text { Unstandardized } \\
\text { Residual }\end{array}$ \\
\hline \multicolumn{2}{|l|}{$\mathrm{N}$} & 80 \\
\hline \multirow{2}{*}{$\begin{array}{l}\text { Normal } \\
\text { Parameters }\end{array}$} & Mean & $0 \mathrm{E}-7$ \\
\hline & $\begin{array}{l}\text { Std. } \\
\text { Deviation }\end{array}$ & 7.60589212 \\
\hline \multirow{3}{*}{$\begin{array}{l}\text { Most Extreme } \\
\text { Differences }\end{array}$} & Absolute & .074 \\
\hline & Positive & .061 \\
\hline & Negative & -.074 \\
\hline \multicolumn{2}{|c|}{ Kolmogorov-Smirnov Z } & .661 \\
\hline \multicolumn{2}{|c|}{ Asymp. Sig. (2-tailed) } & .775 \\
\hline \multicolumn{3}{|c|}{ a. Test distribution is Normal. } \\
\hline \multicolumn{3}{|c|}{ b. Calculated from data. } \\
\hline
\end{tabular}

From the table above shows that the hypothesis test that states the residual distribution in this regression analysis follows the normal distribution. This is indicated by the value of $Z=0.661$ and Sig. $=0.775>0.05$. This means the assumption or requirement of regression analysis is met.

\section{Linearity Test}

The linearity test is performed to determine the technique in the regression analysis whether the variable of vocabulary mastery $(X)$ and the variable of reading comprehension skill $(Y)$ is linear. This linearity test uses SPSS 20.0 calculation 
Table 4.5. Test Results Linearity Regression Variable $Y$ over $X$

\begin{tabular}{|c|c|c|c|c|c|c|c|}
\hline \multicolumn{8}{|c|}{ ANOVA Table } \\
\hline & & & $\begin{array}{l}\text { Sum of } \\
\text { Squares }\end{array}$ & Df & $\begin{array}{l}\text { Mean } \\
\text { Square }\end{array}$ & $\mathrm{F}$ & Sig. \\
\hline \multirow{5}{*}{$\begin{array}{l}\text { Reading } \\
\text { Comprehension } \\
\text { skill * Vocabulary } \\
\text { mastery }\end{array}$} & \multirow{3}{*}{$\begin{array}{l}\text { Betwee } \\
n \\
\text { Groups }\end{array}$} & (Combined) & 1466.569 & 7 & 209.510 & 3.005 & .008 \\
\hline & & Linearity & 1272.708 & 1 & $\begin{array}{r}1272.70 \\
8\end{array}$ & $\begin{array}{r}18.25 \\
2\end{array}$ & .000 \\
\hline & & $\begin{array}{l}\text { Deviation } \\
\text { from } \\
\text { Linearity }\end{array}$ & 193.861 & 6 & 32.310 & .463 & .833 \\
\hline & \multicolumn{2}{|c|}{ Within Groups } & 5020.618 & 72 & 69.731 & & \\
\hline & \multicolumn{2}{|l|}{ Total } & 6487.187 & 79 & & & \\
\hline
\end{tabular}

Based on the above results perhiungan obtained Deviation from Linearity results with Fo $=0.463$ and Sig. $=0.833>0.05$. This has the sense that the variable vocabulary mastery with the reading comprehension skill has a linear relationship.

\section{Hypothesis Test}

The result test of the effect of the vocabulary mastery toward the reading comprehension skill is as in the table below:

Table 4.6. The Result of Multiple Regression Equation of Variables X1 and $\mathrm{X} 2$ on $\mathrm{Y}$

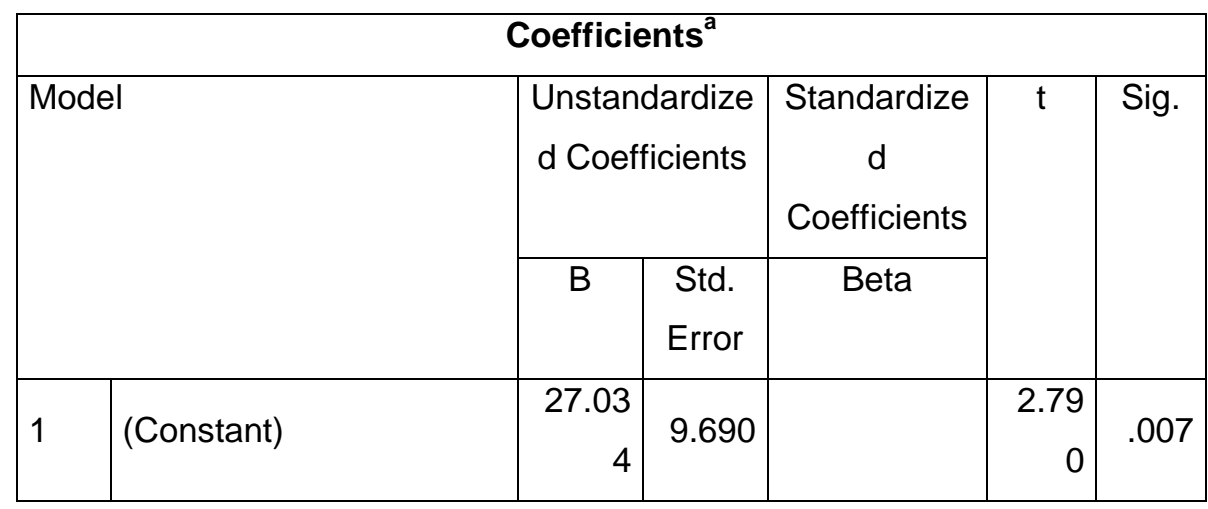




\begin{tabular}{|l|l|r|r|r|r|r|}
\hline & Vocabulary mastery & .267 & .089 & .313 & 3.01 & .003 \\
\cline { 2 - 6 } & Learning style & .352 & .107 & .341 & 3.29 & .001 \\
\hline
\end{tabular}

Hypothesis tested:

H_0: $\beta \_y 2=0$

H_1: $\beta \_y 2 \neq 0$

It means:

$\mathrm{HO}$ : there is no influence of vocabulary mastery on the ability to understand English reading

$\mathrm{H} 1$ : There is an influence of vocabulary mastery on the ability to understand English reading

From table 4.6., it can be stated that there is a significant influence of vocabulary mastery toward the reading comprehension skill. This is evidenced by the acquisition of Sig value. $0.003<0.05$ and th $=3.019$.

The contribution of variable vocabulary mastery toward the reading comprehension skill is:

$\mathrm{KD}=$ Value $\beta \_\mathrm{x} 2 \mathrm{y} \times$ Value of the Pasialnya Correlation $\left(r_{-} \mathrm{x} 2 \mathrm{y}\right) \mathrm{x}$ $100 \%$

$\mathrm{KD}=0.313 \times 0.443 \times 100 \%=13.86 \%$

From the calculation above, it can be stated that the contribution of vocabulary mastery in improving the reading comprehension skill is $13.86 \%$.

\section{Discussion}

From the results of existing research and theory can be concluded that the vocabulary mastery has a positive effect of vocabulary mastery toward the reading comprehension skill for class VIII in the State of Junior High School in Bekasi District. That is, high vocabulary mastery has a significant effect in improving the reading comprehension skill for class VIII in the State of Junior High School in Bekasi District. 
Vocabulary mastery in reading is an important basis of learning in seeking information and knowledge. Someone can improve their knowledge through reading some books, journals, magazines and so on. The ability to read is one of the most important skills to learn. This is because the ability to read is one of the most important ways to improve the general ability in English such as; enriching vocabulary, improving students' comprehence.

\section{CONCLUSION}

In this conclusion, the author describe briefly the results of research obtained in the field can be drawn conclusion that there is a significant effect vocabulary mastery toward the reading comprehension skill for class VIII in the State of Junior High School in Bekasi District. This is evidenced by the acquisition of Sig value. $0.003<0.05$ and th $=3.019$. Variable vocabulary mastery contributes $13.86 \%$ in improving the reading comprehension skill. 


\section{BIBLIOGRAPHY}

Ahmad, H. (2010). Bahasa indonesia untuk perguruan tinggi. Jakarta: Depdiknas.

Akhadiah, S. (1991). Pembinaan kemampuan menulis bahasa indonesia. Jakarta: Gelora Aksara Pramata.

Akhaidah, S., Maidar, G. A., dan Sakura H. R. (1999). Pembinaan kemampuan menulis bahasa indonesia. Jakarta: Erlangga.

Fraenkel, R.J. \& Wallen, N.E. (2007). How to design and evaluate research in education. 6th Ed. McGraw-Hill: Boston.

Halim, A. (1982). Ujian bahasa. Jakarta: Wira Nurbakti.

Harmer, J. (2001). The practice of english language teaching: fourth edition. Essex: Longman Pearson Education Limited.

. (1991). The practice of english language teaching: third edition. New York: Longman Publishing.

Hiebert, E. H. and Kamil, M. L. (2005). Teaching and learning vocabulary: bringing research to practice. London: Lawrence Erlbaum Associates

Keraf, G. (1986). Diksi dan gaya bahasa: komposisi lanjutan I. Jakarta: Gramedia

Nurgiyantoro, B. (2001). Penilaian dalam pembelajaran bahasa dan sastra. Bandung: P.T. Kiblat Buku Utama.

Nurhadi. (1987). Membaca cepat dan efektif. Bandung: Sinar Baru.

Read, J. (2000). Assessing vocabulary. Cambridge: Cambridge University Press.

Schmitt, N., \& McCarthy, M. (1997). Vocabulary: description, acquisition and pedagogy. Cambridge, UK: Cambridge University Press.

Semi, M. A. (1990). Rancangan pengajaran bahasa dan sastra indonesia. Bandung: Angkasa.

Smith, L. E. (1983). Readings in english as an international language. New York: Pergamon Press

Tarigan, D. (1991). Pendidikan bahasa indonesia I. Jakarta: DEPDIKBUD. 
Tarigan, H. G. (2008). Membaca. Bandung: Angkasa

Thornbury, S. (2002). How to teach vocabulary. Essex: Pearson - Longman.

Wiryodijoyo, S. (1989). Membaca: strategi pengantar dan tekniknya. Jakarta: Depdikbud.

Zints, M. V. (1980). The reading process: the teacher and the learner. lowa: Brown Company Publisher. 